\title{
Actual Problems of Development and Standardization of Internal Audit in Russia
}

\author{
Taran O.L. \\ Department of Economics, Management and Finance \\ Pyatigorsk State University \\ Pyatigorsk, Russia \\ oleg-taran@yandex.ru
}

\author{
Soboleva S.Yu. \\ Department of Economics and management \\ Volgograd State Medical University \\ Volgograd, Russia \\ svetlaso@mail.ru
}

\author{
Orobinskaya V.N. \\ Department of Food Technology and Commodity Science \\ School of Caucasus Hospitality Institute of Service, Tourism and Design \\ North-Caucasus Federal University \\ Pyatigorsk, Russia \\ orobinskaya.val@yandex.ru
}

\begin{abstract}
Based on a systematic study of the key problems of development and standardization of internal audit in Russia, the article highlights the key factors of the need to develop internal audit in modern economic conditions and proves the need to introduce internal audit in the practice of economic activity of organizations. Based on the study of existing approaches to the standardization of internal audit, existing both in modern economic science and implemented in practice, they are critically analyzed in terms of classification and an author's chart of the organizational stages of development and approval of the organization's internal audit standards is proposed, which is universal for any organization subject to the conditions for developing internal audit standards, taking into account compliance with applicable laws Islands, audit efficiency and credibility.
\end{abstract}

Keywords—internal audit; internal audit standards.

\section{INTRODUCTION}

In the current economic situation, when a significant number of business entities are influenced by various risk factors for doing business, their primary task is to provide the organization's management system with an independent and high-quality assessment of the effectiveness of financial and economic activities, as well as an assessment of the effectiveness of managerial decisions, both currently and for the future, with particular processes of identifying and reducing the risks of financial and economic activity.

A necessary tool to support these processes is currently an internal audit, capable of effectively performing the functions of monitoring, evaluating and monitoring the effectiveness of both the financial and economic activities of the organization and the adopted tactical and strategic management decisions. In addition, the internal audit is able to very efficiently assess the risks of doing business and give recommendations on their leveling. The above allows us to say that at the present stage, the processes of creating and improving the internal audit system, its organizational and methodological support are becoming particularly relevant.

\section{METHODOLOGY}

The research methodology is based on the use of theoretical and empirical research methods of theoretical and practical material on the research topic. The following methods were also used in the work: statistical, comparativetypological, graphic, analytical, system-logical.

In modern economic literature, to questions of the formation and development of the internal audit system, as well as its importance in controlling and improving the effectiveness of the financial and economic activities of organizations are devoted the works of such domestic and foreign scholars as: O.B. Ivanov, Yu.A. Pavlov, E.Ya. Ostaev V.I. Podolsky, V. Brink, L.D. Parker, J. Robertson and many other researchers. Nevertheless, despite a significant amount of research on internal audit issues, a number of issues related to the practice of implementing internal audit, methodological features of its application, standardization of internal audit in organizations, in our opinion, need further elaboration regarding modern practices of standardization of internal audit and practice of its application.

\section{RESULTS}

In our opinion, the current economic situation dictates the need for the active development and implementation of internal audit in the business practices of organizations of medium and large businesses, in order to improve the efficiency of their activities. At the same time, it is necessary to understand that the development of internal audit is necessary even for those organizations that, in accordance with applicable law, are subject to annual mandatory external audit, because, firstly, external and internal audits have different goals - if the external audit serves mainly the interests of the external users, then internal audit is of most 
activity of organizations, in a sense, the impetus for a more effective implementation and development of the internal audit system can serve standardization of internal audit procedures, actively implemented in Russian practice.

In modern conditions, the active use and observance of the International professional standards of internal audit is able to systematize the work of internal auditors and orient them towards a more active use of consulting tools in their activities. Internal audit in the activities of modern Russian organizations is not yet sufficiently developed, which is primarily due to the lack of regulation of internal audit procedures, as well as the lack of unification of internal audit standards, on which the quality of internal audit and its effectiveness depend primarily.

Typically, the standardization process of internal audit in organizations is carried out independently using international professional standards for internal audit as the basis for their development. Nevertheless, the use of internal audit standards, in our opinion, in modern economic conditions is an urgent need, including dictated by global trends. It is for this reason that it is necessary to consider existing approaches to the interpretation of the concept of "Internal Audit Standards", existing both in modern economic science and implemented in practice.

The International Institute of Internal Auditors, notes that "Standards are a set of requirements formulated in the form of principles consisting of: the main text - the definition of key standards used to organize the professional activities of internal audit and to assess the effectiveness of activities that can be applied at the organization level and individual workers worldwide; interpretations clarifying terms or conceptual approaches used in the Standards" [3].

Gallyamova T.R., Ostaev E.Ya., Kontsevaya S.R. in their research, they note that the standards of internal audit are the development of standards for internal audit in organizations enshrined in regulatory documents that contribute to the provision of information, ensure the safety of assets, ensure the efficiency of economic activity and ensure compliance with relevant regulations [4].

The code of ethics of internal auditors states - "Under the internal standards of audit activity we mean normative documents that determine the uniform requirements for conducting audits, filling out the results of inspections, the procedure for preparing final documents, preparing and forming internal auditors" [9].

Pavlova Yu.A. in her research notes that the internal audit standard is a local act aimed at standardizing the activities of structural units of the organization that perform the functions of internal audit [5].

Paramonova L.A. notes: "By internal standards for the organization and functioning of internal audit are understood documents that detail and regulate the unified requirements for the implementation of internal audit and presentation of the results of its implementation, adopted and approved by the organization in order to ensure the effectiveness of practical work and its adequacy to the requirements of the legislation of the Russian Federation on accounting and tax accounting. The 
approved by the Ministry of Finance of the Russian Federation. So, in particular, Pervova K.A. in her study identifies standards that determine the procedure for conducting an internal audit and interaction with external auditors, organizational standards, and standards that govern the procedure for generating reports [7].

Ivanov O.B. comes more broadly to the classification system of internal audit standards; in his study, in addition to the main standard and the standard for preparing a report, he outlines standards for planning internal audit reviews, conducting internal audit reviews, planning activities and managing the resources of the internal audit and control division, conducting an audit of the risk management system [2].

Gallyamova T.R., Ostaev E.Ya., Kontsevaya S.R. offer standards with the inclusion of detailed programs in them and offer the following classification: program-thematic standards, program-operational standards, program-resultant standards, program-target standards [4].

The considered approaches to the classification system of internal audit standards allowed us to draw the following conclusion - the system of internal audit standards in modern Russian practice is a kind of modeling of existing internal audit standards taking into account the specifics and scope of the business entity, as well as approaches to organizing the organization's management system taking into account requirements of modern legislation.

The above allows us to offer the author's scheme of organizational stages of development and approval of the organization's internal audit standards (Figure 2).

The scheme we propose, in our opinion, is universal for any organization, subject to the conditions for the development of internal audit standards, taking into account the objectives of compliance with applicable law, audit efficiency and its reliability.

When using internal audit standards, it is necessary to take into account that the internal audit itself can apply the audit approaches adopted in the external audit, namely the operational approach, the accounting approach, the cyclical approach, the audit approach, the process-object approach, the risk-based approach, the compliance approach, the choice of approach depends on the specifics of doing business, accounting policies, organizational and legal form of the business entity and other factors that unify one or another business entity.
The requirements for internal standards of audit organizations approved by the Audit Commission under the President of the Russian Federation (Protocol No. 6 dated October 20, 1999) state that "Internal standards of audit organizations for their intended purpose can be grouped into the following groups: standards containing general audit provisions; standards establishing the audit process; standards establishing the procedure for the formation of conclusions and conclusions of auditors; specialized standards; standards establishing procedures for the provision of audit-related services; standards for education and training" [8].

A number of Russian authors approach the classification system of internal audit standards in more detail, which is primarily due to the lack of relevant federal standards 
do not apply to internal audit, as Federal Law No. 307-FZ "On Auditing" indicates "To auditing activities do not include audits carried out in accordance with the requirements and in a manner different from the requirements and procedures established by the standards of auditing", and since internal auditors are working the organization's standards, and therefore the internal audit standards, are the business of a separate economic entity, all the more so because the domestic standard contains the professional standard "Internal Auditor", approved by Order of the Ministry of Labor of the Russian Federation dated 24.06.2015 No. 398n, according to which the internal auditor is responsible for monitoring the management system risks, corporate governance, monitors the safety of the organization's assets and the accuracy of information received by management, compliance with legislation.

In addition, international professional standards for internal audit also determine that the goals, powers and responsibilities of internal auditors are determined by the local act of the enterprise, although the same requirements are set for internal auditors as for external auditors, and this is in accordance with Federal Law No. 307-FZ: independence, objectivity, professionalism, discretion, business continuity. Thus, we can say that internal auditors perform broader control functions in relation to their organization and, unlike external auditors, check not only financial statements, but also other areas and areas of activity of their organization in accordance with internal local legal acts organization.

Using these recommendations can improve the quality of internal audit as an activity to assess the effectiveness of an economic entity in terms of the reliability and effectiveness of financial and economic activities aimed at developing proposals for its optimization to achieve strategic initiatives and mitigate risks, which in general will undoubtedly affect efficiency activities of the organization applying internal audit.

\section{CONCLUSION}

Based on a review of the approaches available in open sources to the definition of internal audit standards, we can conclude that there is no single approach to the interpretation of the concept of "internal audit standards". In our opinion, the interpretation of the concept under consideration given by the International Institute of Internal Auditors is the broadest, most comprehensive and accumulating in itself all the other interpretations we consider by other authors.

The considered approaches to the classification system of internal audit standards allowed us to draw the following conclusion - the system of internal audit standards in modern Russian practice is a kind of modeling of existing internal audit standards taking into account the specifics and scope of the business entity, as well as approaches to organizing the organization's management system taking into account requirements of modern legislation.

The above allowed us to propose the author's scheme of organizational stages of development and approval of the organization's internal audit standards. The scheme we propose, in our opinion, is universal for any organization, subject to the conditions for the development of internal audit 
uchet. - 2012. - № 45 (243). - S.49-55. - URL: https://cyberleninka.ru/article/v/formirovanie-i-standartizatsiyavnutrennego-audita-v-kommercheskih-organizatsiyah

[5] Pavlova YU.A. Sovershenstvovanie mekhanizma vnutrennego audita krupnykh kompaniy na osnove protsessa planirovaniya [Ehlektronnyy resurs] // Ehkonomicheskiy vestnik Rostovskogo gosudarstvennogo universiteta. - 2009 - №4. - S. 95-98. -= URL: https://booksc.org/book/36551566/ce59ff

[6] Paramonova L.A. Vnutrifirmennye standarty funktsionirovaniya sistemy vnutrennego audita [Ehlektronnyy resurs] // Vestnik Volzhskogo universiteta im. V.N. Tatishcheva. - 2011. - № 24. - S. 107-113. - URL: https://cyberleninka.ru/article/v/vnutrifirmennye-standartyfunktsionirovaniya-sistemy-vnutrennego-audita

[7] Pervova K.A. Metodologicheskie aspekty vnutrennego audita na predpriyatii [Ehlektronnyy resurs] // Biznes v zakone. Ehkonomikoyuridicheskiy zhurnal. - 2013. - № 5. - S. 244-246. - URL: https://cyberleninka.ru/article/v/metodologicheskie-aspektyvnutrennego-audita-na-predpriyatii

[8] Pravilo (standart) auditorskoy deyatel'nosti «Trebovaniya, pred"yavlyaemye k vnutrennim standartam auditorskikh organizatsiy» [Ehlektronnyy resurs] (odobreno Komissiey po auditorskoy deyatel'nosti pri Prezidente RF 20.10.1999 Protokol № 6). - Rezhim dostupa: http://www.consultant.ru/cons/cgi/online.cgi?req=doc\&base=LAW\&n= $25134 \&$ fld $=134 \& \mathrm{dst}=1000000001,0 \& \mathrm{rnd}=0.056687015704767196 \# 016$ 442144169929507

[9] Standarty vnutrennikh auditorov [Ehlektronnyy resurs]. - URL: http://geum.ru/kurs/standarty_vnutrennih_auditorov.php

[1] Ivanov O.B. Praktika OAO «Rossiyskie zheleznye dorogi» po postroeniyu risk-orientirovannoy sistemy vnutrennego kontrolya $\mathrm{i}$ audita [Ehlektronnyy resurs] // Ehkonomicheskie nauki. - 2014. - № 1 (110). S. 111-116. - URL: http://ecsn.ru/files/pdf/201401/201401_111.pdf

[2] Ivanov O.B. Formirovanie sistemy vnutrennego kontrolya, audita i upravleniya riskami $\mathrm{v}$ kompanii na osnove vnutrikorporativnykh standartov [Ehlektronnyy resurs] // Ehtap: ehkonomicheskaya teoriya, analiz, praktika. - 2012. - № 2. - S. 4-23. - URL: https://cyberleninka.ru/article/v/formirovanie-sistemy-vnutrennegokontrolya-audita-i-upravleniya-riskami-v-kompanii-na-osnovevnutrikorporativnyh-standartov

[3] Mezhdunarodnye professional'nye standarty vnutrennego audita (Standarty) [Ehlektronnyy resurs]. - URL: https://www.iiaru.ru/contact/Standards-rus\%202016\%20IIA\%2027122016.pdf

[4] Ostaev E.YA. Formirovanie i standartizatsiya vnutrennego audita v kommercheskikh organizatsiyakh // Mezhdunarodnyy bukhgalterskiy
[10] Taran O.L., Adzhienko V.L., Taran I.L. Sanatorium-resort and tourist sphere for the competitiveness of stavropol territory (part 1) The European Proceedings of Social \& Behavioural Sciences EpSBS eISSN: $2357-1330 \quad$ (C)2019 Published by the Future Academy.https://dx.doi.org/10.15405/epsbs.2019.04.115

[11] Alexsandr S. Kuznetsov. Russian Professor's meeting. Russian Journal of Physical Education and Sport. 2019, 14(1), pp. 17-22. DOI: 10.14526/2070-4798-2019-14-1-18-24

[12] Taran O.L., Adzhienko V.L., Taran I.L. Sanatorium-resort and tourist sphere for the competitiveness of stavropol territory (part 2) The European Proceedings of Social \& Behavioural Sciences EpSBS eISSN: 2357-1330 $\quad$ C2019 Published by the Future https://dx.doi.org/10.15405/epsbs.2019.04.116 